\title{
Health Conditions and Dangers Due to Work for Fishers in Pangandaran District, West Java
}

\author{
Neti Juniarti, Hartiah Haroen, Desy Indra Yani \\ Department of Community Health Nursing, Faculty of Nursing, Universitas Padjadjaran, Sumedang, Indonesia
}

\begin{abstract}
Work safety and health are essential for fishers in Pangandaran Beach because these fishers were not paying attention to their work health and safety. This attitude would pose a high risk for the fishers due to the weather conditions that can turn wild in a short period and can cause an elevated risk of an accident. This study aimed to identify the health conditions, hazards, and work accidents that were experienced by Pangandaran fishers. The methods used quantitative descriptive. The survey conducted in Pangandaran subdistrict, West Java in November 2017. The samples were recruited purposively, and a total of 17 fishers were willing to participate. The data were analyzed using descriptive univariate analysis. The results showed that 7 of 17 fishers have a health problem, and most of them have high blood pressure. All participants had experienced accident during their work, dan only 9 of 17 who wear safety equipment. Hazardous work hazard is a green jellyfish sting during fishing. Thus, it is recommended to the public health center, Regency Health Office, and Fisheries Office to establish the fishers' health post, which is close to the beach. And also provide training about first aid in the event of an accident of jellyfish stung.
\end{abstract}

Key words: Fishers' health, protection device, work safety

\section{Kondisi Kesehatan dan Bahaya Akibat Kerja pada Nelayan di Kecamatan Pangandaran, Jawa Barat}

\begin{abstract}
Abstrak
Keselamatan dan kesehatan kerja sangat penting untuk para nelayan yang bekerja di sekitar pantai Pangandaran karena para nelayan di pantai Pangandaran masih kurang memperhatikan keselamatan dan kesehatan kerja. Hal ini sangat berisiko untuk keselamatan nelayan karena cuaca di pantai dan laut dapat berubah dengan cepat dan mengakibatkan risiko kecelakaan yang sangat tinggi. Penelitian ini bertujuan mengetahui kondisi kesehatan dan bahaya serta kecelakaan kerja yang dialami oleh nelayan di Kecamatan Pangandaran. Metode penelitian menggunakan deskriptif kuantitatif. Penelitian ini dilakukan di Kecamatan Pangandaran, Jawa Barat pada bulan November 2017. Penarikan sampel dilakukan secara purposive dan jumlah sampel sebanyak 17 orang. Data dianalisis menggunakan analisis univariat. Hasil penelitian menunjukkan bahwa 7 dari 17 nelayan memiliki masalah kesehatan dengan jumlah terbanyak menderita hipertensi. Semua responden pernah mengalami bahaya dan kecelakaan akibat kerja, serta hanya 9 dari 17 yang menggunakan pelampung. Bahaya kesehatan yang paling besar dikeluhkan oleh nelayan adalah sengatan ubur-ubur hijau. Oleh karena itu, disarankan pada pihak puskesmas, Dinas Kesehatan, serta Dinas Perikanan dan Kelautan setempat untuk membentuk pos usaha kesehatan kerja nelayan di Pangandaran, serta memberikan pelatihan tentang penanganan kecelakaan dan perawatan pasien yang terkena sengatan ubur-ubur hijau.
\end{abstract}

Kata kunci: Alat pelindung diri, kesehatan nelayan, keselamatan kerja

Received: 19 December 2017; Revised: 25 August 2019; Accepted: 20 December 2019; Published: 31 December 2019 


\section{Introduction}

A healthy paradigm approach is vital for fishers to improve their health conditions through occupational health and safety (OHS) efforts. Occupational health and safety is also essential to apply to the informal sector, such as fishers in Pangandaran subdistrict, Pangandaran regency is one of the regencies in West Java province, which has only been a Regency Government since 2012. ${ }^{1}$

This regency is strategically located, because it is situated on a provincial road, is on the coast with a length of $91 \mathrm{~km}$, and has a variety of potential to be developed. Pangandaran regency is a district in West Java province whose capital is in Parigi. This regency is bordered by Ciamis regency and Banjar city in the north, Cilacap regency in the east, the Indian Ocean in the south, and Tasikmalaya Regency in the west. ${ }^{1}$ The birth of the Pangandaran regency was based on Law Number 21 of 2012 as a new district (daerah otonom baru/DOB), which was signed by the President of Republic of Indonesia on 2012 November 16. ${ }^{2}$ Then it was promulgated by the Minister of Law and Human Rights on 2012 November 17, later Pangandaran officially became a regency in West Java province. The Law Number: 21/2012 stated Pangandaran regency came from a part of the Ciamis regency. ${ }^{2}$ The area of Pangandaran regency is 168,509 ha with a sea area of 67,340 ha. ${ }^{1}$

Pangandaran regency has a beach length of $91 \mathrm{~km}$. The total population, according to sex in 2014, women numbered 212,022 people, and men totaled 210,564 people. The government covers ten subdistricts, namely Parigi subdistrict, Cijulang subdistrict, Cimerak subdistrict, Cigugur subdistrict, Langkaplancar subdistrict, Mangunjaya subdistrict, Padaherang subdistrict, Kalipucang subdistrict, Pangandaran subdistrict and Sidamulih subdistrict. ${ }^{1}$

The highest number of fishers is in the Pangandaran subdistrict, which is 2,935 people, with a total of 4,141 in 2015. ${ }^{1}$ Considering the decreasing number of fishers in the Pangandaran subdistrict, it is necessary to study health conditions and work-related hazards for fishers to improve OHS.

Occupational health and safety is a condition and factors that affect the health and safety of employees or other workers (including temporary workers), visitors, or other people in the work area. ${ }^{3}$ In the framework of ensuring occupational safety and health in Indonesia, Law Number 23 of 2003 concerning workforce article 86 states that every worker has the right to obtain protection for occupational safety and health. ${ }^{4}$

Occupational health and safety are needed to overcome risks that can arise in the scope of work, where the risk is a combination of the possibility of danger or exposure and the severity of injuries or health problems that can be caused by an event or exposure. The importance of occupational health and safety efforts because every work accident that occurs will cause economic losses, such as damage to machinery, equipment, building materials, medical costs, and accident compensation costs. Therefore, by taking steps to prevent accidents, in addition to preventing injury to workers, it can also save costs. ${ }^{3}$

Occupational safety and health are also crucial for fishers who work around Pangandaran beach. Based on the observation of researchers, the fishers on Pangandaran beach still pay less attention to occupational safety and health, such as not using proper footwear, not using personal protective equipment and safety buoys. It is very risky for the protection of fishers because the weather on the beach and sea can change quickly and result in a very high risk of accidents. The results also showed that fishers in the Thousand islands experienced hazards for worker safety including waves, slippery floors, fish spines, pinched, compressor engine fuel, corrosive fire hose, air pressure on the compressor engine tube, release levers, corals, bites of marine life, the tubing is bent, broken, or leaking and the body is stuck in the propeller of the ship. Health hazards include ergonomics, noise, extreme pressure, cold temperatures, hot temperatures, stinging fish and poisonous corals, $\mathrm{CO}$ gas, $\mathrm{CO}_{2}$, and nitrogen. ${ }^{5}$

According to studies, efforts can be made to prevent health problems and work-related accidents there are five levels, namely health promotion, specific protection, early diagnosis and prompt treatment, disability limitation, and ehabilitation. ${ }^{6}$

Health promotion consists of health education for workers, improvement, and improvement of workers' nutrition, healthy development of workers' psychology, provision of robust worker housing, recreation for workers, provision of a healthy workplace and environment, inspection before work, attention to descent factors. ${ }^{6}$

The activities that can be carried out in 
terms of specific protection include complete immunization, good work hygiene, sanitation of a healthy work environment, protection against work hazards, control of work-related dangers so that they are safe, protection against carcinogenic factors, avoid causes of allergies, human association (workers) with machines. ${ }^{6}$

Early diagnosis and prompt treatment encompass activities including looking for workers, both individuals or groups, to certain disease disorders, regular general check-ups for workers, screening. ${ }^{6}$

Disability limitation can be done to prevent disability is an adequate treatment to prevent and stop the disease process, excellent care, provision of facilities to limit disability and to avoid death. Rehabilitation can be done through training and education to train existing capabilities, community education to use disabled workers, selective placement of disabled workers, work therapy in hospitals, providing a protected workplace. ${ }^{6}$

Based on this background, a study was conducted on health conditions and hazards resulting from work for fishers in the Pangandaran subdistrict area. The general objective of this study is to improve primary health services in fishers groups through occupational health nursing care at Pangandaran beach in achieving optimal quality of life.

\section{Methods}

This research was a quantitative descriptive study. This research was conducted in Pangandaran subdistrict in November 2017. Sampling was done purposively, and the number of samples was 17 because of the difficulty of meeting fishers, and many fishers refused to be investigated on the grounds they were preparing nets for fishing. To respect participant rights, researchers only included data from fishers who voluntarily participated in this study. Fishers' health checks were carried out by three researchers with nursing education backgrounds. When checking, participants did not feel awkward, giving comments or answers. Before data collection, researchers had obtained ethical approval from the Health Research Ethics Committee, Faculty of Medicine, Universitas Padjadjaran (letter number: 820/UN6.C10/PN/2017) and research permission from the Health Officer and the Office of the Indonesian Unity and Politic Pangandaran.
Data were analyzed using descriptive statistics to describe health conditions and occupational hazards experienced by fishers while working.

\section{Results}

The number of samples collected was 17 fishers. The results of physical health checks and occupational health counseling for these fishers obtained demographic data from 17 fishers along with several health problems and work accidents they have experienced. Table 1 shows demographic data and fishers health problems in Pangandaran.

Based on Table 2, the fishers in Pangandaran experienced various health problems. Looking at the fishers' health data, follow up on the efforts of primary health care following the existing issues is essential.

In addition to health problems experiencing health problems, the fishers also suffered work accidents while at sea. This data is presented in Table 3 .

Table 3 shows that the two prominent work hazard was biological such as being bitten by a fish or being stung by green jellyfish and ergonomic problems. When asked about the use of personal protective equipment (PPE), the fishers answered varied as presented in Table 4.

From Table 4, it can be seen that awareness to use personal protective equipment, especially buoys, masks, and boots, was still quite low.

\section{Table 1 Fishers Respondent Demographic Data}

\begin{tabular}{lc}
\hline Demographic Data & $\mathbf{f}(\mathbf{n}=\mathbf{1 7})$ \\
\hline Age (year) & \\
$<20$ & 1 \\
$21-30$ & 3 \\
$31-40$ & 1 \\
$41-50$ & 4 \\
$51-60$ & 8 \\
Gender & \\
Male & 16 \\
Female & 1 \\
Working period as a fishers (year) & \\
O-9 & 2 \\
10-19 & 4 \\
$20-29$ & 5 \\
$30-39$ & 3 \\
$>40$ & 3 \\
\hline
\end{tabular}


Table 2 Health Problems Encountered by Fishers

\begin{tabular}{lc}
\hline Type & $\mathbf{f}(\mathbf{n = 1 7})$ \\
\hline Health condition & \\
Healthy & 10 \\
Unhealthy & 7 \\
Illness experienced & \\
Gout and rheumatism & 3 \\
Flu & 2 \\
Toothache & 1 \\
Back pain & 1 \\
High blood pressure & 10 \\
\hline
\end{tabular}

\section{Discussion}

These fishers work from early morning until morning, and they return home around $11 \mathrm{am}$. After that, they will get enough rest and sleep to get tired after working. It makes it difficult for the fishers to access services at the public health center (PHC) because PHC service hours are open from 08:00 to 14:00. By doing family nursing care, fishers can be visited at their homes at a time that suits their conditions after resting and taking a nap. Thus, occupational health nursing is needed to provide nursing care and health check-up for the traditional fishers. Occupational health nursing is a branch of community health care that provides services to workers or groups of workers. Services focus on health promotion, protection, and recovery of the workforce's health about safety and a healthy work environment.?

Occupational health nursing is the application of nursing and public health as well as skills

Table 3 Work Hazards and Accidents Experienced by Fishers

\begin{tabular}{lc}
\hline Types of Work Accidents & $\mathbf{f}(\mathbf{n}=\mathbf{1 7})$ \\
\hline Work accidents & \\
Bitten by a fish or stung by a & 9 \\
jellyfish & 7 \\
Leaking boat or boat overturned & 1 \\
Fell from the boat & \\
Ergonomic problems & \\
Yes & 12 \\
No & 5 \\
Chemical hazard & \\
Yes & 8 \\
No & 9 \\
\hline
\end{tabular}

Table 4 Personal Protective Equipment Used

\begin{tabular}{lc}
\hline $\begin{array}{l}\text { Type of Personal Protective } \\
\text { Equipment }\end{array}$ & $\mathbf{f}(\mathbf{n}=\mathbf{1 7})$ \\
\hline Live vest & \\
Yes & 9 \\
No & 8 \\
Raincoat & \\
Yes & \\
No & 11 \\
Gloves & 6 \\
Yes & \\
No & 15 \\
Mask & 2 \\
Yes & \\
No & 1 \\
Hat/helm & 16 \\
Yes & \\
No & 13 \\
Boots & 3 \\
Yes & \\
No & 2 \\
\hline
\end{tabular}

related to workers for the prevention of illness and accident as well as health improvement in an optimal, productive and socially acceptable manner. ${ }^{8}$

The results of this study indicate that almost half of fishers experience health problems due to work. Factors that can cause health problems include workload, the additional burden due to the environment, work capacity. ${ }^{8}$

The workload is a workload that must be borne by workers, which can be physical, mental, or social. If the workload exceeds work capacity, it can cause health problems. The additional burden due to the environment is the workload obtained due to the work environment that does not support the work process. Potential hazards consists of physical factors in the form of noise, temperature, vibration, pressure; chemical factors for example gas, dust, $\mathrm{CO}$, insecticides; biological factors such as viruses, bacteria and other organisms; and psychological mental factors, in the form of demands, policies or management of companies that do not support, social relations that are not harmonious; and ergonomics.

Work capacity is the ability of a worker in carrying out his work. Work capacity depends on the skills mastered by workers, sex, age of 
workers, body proportions, work nutrition, harmony in practice. The results of this study indicate that there are several burdens and hazards experienced by fishers. It is in line with research which states that there are many occupational hazards encountered by fishers. ${ }^{5}$ This work hazard is also aggravated by fishers' health conditions, that are less than optimal. It is in line with the results of research that shows that the health of fishers in East Lombok regency was still relatively low even though the local Health Office has sought measures to improve the health of fishers' work. ${ }^{9}$

Occupational health care is carried out to protect the health of workers from potential threats emanating from the workplace and helping workers to create a work environment that is appropriate to their physical, mental, and emotional capacities. Thus, the efficiency levels can be achieved without conditions that endanger health and safety, guaranteeing service adequate health and rehabilitation from illness and injury, and encourage workers to maintain optimal health. ${ }^{8}$ It is not only done by workers in large companies, but fishers groups also need to get optimal occupational health care.

Occupational health nurses can provide direct care which includes carrying out assessments according to the health needs of workers, formulating nursing diagnoses of nursing, planning, implementing actions and evaluating the impact of interventions; provide health services related to preventing, maintaining and correcting health problems. ${ }^{10,11}$

All respondents stated the need for Fishers Occupational Health Posts close to the beach, and they can use them if there are accidents and emergency conditions when they are work so that they don't have to go far to the PHC if they want to have their blood pressure or health condition checked. Nurses can play a role in coordinating administrative and service functions for the fishers to achieve cost-effective measures. As a manager/ administrator, nurses can create programs to improve worker health by applying management principles (using SWOT analysis in assessing, determining needs, planning, implementing the program, conducting monitoring and evaluating programs. ${ }^{8}$ The other role of the nurse is as an educator to do health education for workers about risk management, prevention of illness and injury, the use of personal protective equipment, and others. The nurse is also a researcher to develop the program based on research results. ${ }^{10,11}$

Occupational health nursing care begins with the assessment until evaluation. Assessment in occupational health consists of assessing human biology, including characteristics of age and sex, genetic health problems of workers, physical function by identifying various body systems. Environmental assessment includes multiple potential hazards that can cause health problems due to work include physical, biological, chemical, psychosocial, ergonomic hazards. Lifestyle assessment includes patterns of food consumption, activity and rest, appearance at work, use of self-supporting devices. Assessment of the health system which consists of a health service system (referral), a monitoring program related to occupational safety, existing health promotion policies and programs, limitations, and promotion and protection efforts, a health care system for working families. ${ }^{10,11}$

In accordance with the results of another study, it is known that there are several factors associated with the disease occurrence in fishers, including that the length of service $(p=0.001)$, personal protective equipment (PPE, $\mathrm{p}=0.001$ ), work history $(\mathrm{p}=0.027)$, own health $(\mathrm{p}=0.027) .{ }^{12}$ It is also in line with the results of this study, which shows that most fishers have more than ten years of service, inadequate use of personal protective equipment and are a matter of their health. Another factor that also affects health is the level of welfare of fishers. The results showed that $15 \%$ of fishers had a high level of welfare, while $85 \%$ had a medium level of welfare. ${ }^{13}$

After the assessment, a nursing diagnosis is carried out, which includes the client's health status, occupational illness, at-risk population, workplace hazards. This diagnosis is intervened by compiling a problem-solving plan in occupational health nursing that includes three levels of prevention consisting of After the assessment, a nursing diagnosis is carried out, which includes the client's health status, occupational illness, at-risk population, workplace hazards. This diagnosis is intervened by compiling a problemsolving plan in occupational health nursing that includes three levels of prevention consisting of primary prevention, secondary prevention, and tertiary prevention..$^{10}$

Included in primary prevention activities are health promotion provides health education activities, improvement of nutrition, rest, and exercise for workers; prevention of 
diseases includes reducing risk factors, giving immunizations, stress management; and injury prevention, which includes safety education, the use of personal protective equipment (PPE), handling dangerous substances, reducing hazards that threaten safety, improving ergonomic health. ${ }^{10}$

Included in secondary prevention efforts are screening workers, periodic health checks, examining environmental aspects that could pose a hazard to workers; case management; and emergency handling which includes physical, psychological, and work-related accidents. ${ }^{10}$

Included in secondary prevention activities include prevention of the spread of infectious diseases; prevention of recurrence; prevention of complications; and worker rehabilitation. ${ }^{10}$

Planning related to fisheries management and the fishers' health needs to be prepared by involving fishers as actors and also involving other stakeholders. ${ }^{14}$ The fishers are partners of occupational health nurses to improve the degree of public health. ${ }^{10}$

\section{Conclusions}

It can be concluded that fishers have various health problems, have experienced work hazards and accidents, as well as paying less attention to the use of personal protective equipment. The most significant health hazard complained of by fishers is the sting of green jellyfish. Therefore it is suggested to the community health center, the Health Service, and the local Fisheries and Maritime Service to establish a Fishers Occupational Health Post in Pangandaran, as well as provide training on accident management and treatment of patients affected by green jellyfish stings.

\section{Conclusions}

It can be concluded that fishers have various health problems, have experienced work hazards and accidents, as well as paying less attention to the use of personal protective equipment. The most significant health hazard complained of by fishers is the sting of green jellyfish. Therefore it is suggested to the community health center, the Health Service, and the local Fisheries and Maritime Service to establish a Fishers Occupational Health Post in Pangandaran, as well as provide training on accident management and treatment of patients affected by green jellyfish stings.

\section{Conflict of Interest}

All authors state there was no conflict of interest.

\section{References}

1. Badan Perencanaan Pembangunan Daerah (Bappeda) Pemerintah Provinsi Jawa Barat. Laporanakhirpenyusunanrencanakebutuhan investasi pusat pertumbuhan Pangandaran Raya [Internet]. Bandung: Bappeda Jawa Barat; 2016 [cited 2017 August 10]. Available from: http://bappeda.jabarprov.go.id/wpcontent/uploads/2017/o3/Laporan-AkhirKebutuhan-Inv-Pangandaran-Raya.pdf.

2. Undang-Undang Republik Indonesia Nomor 21 Tahun 2012 tentang Pembentukan Kabupaten Pangandaran di Provinsi Jawa Barat.

3. Suma'mur. Higiene perusahaan dan kesehatan kerja (Hiperkes). Jakarta: Sagung Seto; 2009.

4. Undang-Undang Republik Indonesia Nomor 23 Tahun 2003 tentang Ketenagakerjaan.

5. Dharmawirawan DA, Modjo R. Identifikasi bahaya keselamatan dan kesehatan kerja pada penangkapan ikan nelayan Muroami. Kesmas. 2012;6(4):185-92.

6. Efendi F, Makhfudli. Keperawatan kesehatan komunitas: teori dan praktik dalam keperawatan. Jakarta: Salemba Medika; 2009.

7. American Association of Occupational Health Nurses. What is occupational \& environmental health nursing? [Internet]. AAOHN, Inc. 2017 [cited 2017 December 19]. Available from: http://aaohn.org/ page/profession-of-occupational-andenvironmental-health-nursing.

8. Oakley K. Occupational health nursing. $3^{\text {rd }}$ Edition. Chichester, England: John Wiley \& Sons; 2008.

9. Martiana T, Wilujeng LK. Upaya kesehatan kerja sektor informal dan lingkungan perumahan nelayan di Kabupaten Lombok Timur NTB. JKL. 2006;2(2):153-62.

10. Anderson ET. Community health nursing: essentials of practice. In: Anderson ET, McFarlane J, editors. Community as partner: theory and practice in nursing. $7^{\text {th }}$ Edition. 
Philadelphia: Wolters Kluwer; 2015. p. 1928.

11. Kulbok PA, Thatcher E, Park E, Meszaros P. Evolving public health nursing roles: focus on community participatory health promotion and prevention. Online $\mathrm{J}$ Issues Nurs. 2012;17(2):1.

12. Cahyawati IN, Budiono I. Faktor yang berhubungan dengan kejadian dermatitis pada nelayan. Kemas. 2011;6(2):134-41.

13. Sugiharto E. Tingkat kesejahteraan masyarakat nelayan Desa Benua Baru Ilir berdasarkan indikator Badan Pusat Statistik.
EPP. 2007;4(2):32-6.

14. Monintja D, Yusfiandayani R. Pemanfaatan sumberdaya pesisir dalam bidang perikanan tangkap. In: Bengen DG, editor. Prosiding Pelatihan Pengelolaan Wilayah Pesisir Terpadu; 2001 October 29-November 3; Bogor, Indonesia. Bogor: Pusat Kajian Sumberdaya Pesisir dan Lautan, Institut Pertanian Bogor; 2001 [cited 2017 December 28]. p. 56-65. Available from: https://www. crc.uri.edu/download/Proceeding_ToT_ ICM.pdf. 